\title{
When European integration becomes costly: The Euro crisis and public support for European economic governance
}

Theresa Kuhn and Florian Stoeckel

[Accepted for publication, Journal of European Public Policy]

\begin{abstract}
This paper analyses preferences for European economic governance in the European sovereign debt crisis. We assess citizens' opinions on increased intergovernmental cooperation and supranational governance in the economic sphere. We argue that current efforts to tackle the Euro crisis do not benefit the typical 'winners of European integration'. Moreover, European economic governance constitutes an even greater perceived threat to national identity, especially in the member states that fare well economically. Hypotheses are tested using multilevel analysis of Eurobarometer survey wave EB 75.3 (2011).
\end{abstract}

KEY WORDS European economic governance; macro-economic conditions; national identity; attitudes; sovereign debt crisis. 


\section{INTRODUCTION}

The current sovereign debt crisis has put a price tag on the aim of unifying Europe. Bailouts of inconceivable amounts have been granted to Ireland, Portugal, Greece, and Cyprus, and have made it clear that the willingness to integrate European national societies has its material price for everyone. While economically stable countries have to stand in for their crisis-struck neighbouring countries, receiving countries forgo important economic decision-making power, and are forced to implement rigid austerity measures that are highly unpopular and put many citizens under economic strain.

Against the backdrop of this crisis, European economic governance is subject of heated debate. Consequently, this article asks to what extent European citizens support European economic governance in the crisis. Are those who are most likely to benefit from economic governance willing to accept it? Journalistic accounts of mass protests against financial bail-out packages are abound, but there is little systematic evidence on who are the Europeans that are in favour or against European economic governance in the crisis. This is problematic for two reasons. First, in view of democratic legitimacy, we need to know to what extent the decisions taken by a small group of relatively independent actors are actually supported by European citizens. Second, on a theoretical level, it is important to know whether support for European economic governance is mainly driven by self-interest or by sociotropic considerations relating to the nation-state or the European Union (EU).

Therefore, this paper analyses the factors determining citizens' preferences for European economic governance in the sovereign debt crisis, i.e. increased intergovernmental cooperation and supranational regulation and oversight. Intuitively, one would expect that support for European economic governance was structured similarly to EU support at large. In other words, people who favour European integration should also favour increased economic cooperation to solve the sovereign debt crisis. However, as we show in this paper, EU support and support for 
European economic governance are not one and the same thing. European economic governance in the current crisis differs from 'European integration as usual' in two fundamental ways. First, while European integration has focussed on market liberalization (Crespy 2010), current steps in economic governance go in a different direction by imposing regulation and increased (supranational) oversight on banks and markets. This is likely to yield a different winner-loser structure than the liberalizing measures taken in pre-crisis Europe. We therefore expect that contrary to EU support, support for European economic governance is stronger among individuals that rely on a strong welfare state, and in states that do not fare well economically.

Second, European economic governance in the crisis implies that national sovereignty is delegated to the supranational level to an even greater extent than before - especially among countries that do not form part of the Eurozone. In the past twenty years, European integration has provoked scepticism among people that primarily identify with their nation state (Carey 2002; Hooghe and Marks 2005; McLaren 2006). We argue that the pooling of macro-economic sovereignty in the crisis poses an even greater challenge to national identity than European integration. Economic and Monetary Union already constituted a remarkable retrenchment of macro-economic sovereignty among the countries that had decided to join the Eurozone. However, current steps in European economic governance are decidedly more far-reaching. They involve novel, specific and binding regulatory procedures and concern member states that had chosen to stay out of the Euro. Moreover, while the emphasis so far has been on what Scharpf (1997) coined 'negative integration', current measures are characterized by 'positive integration', which is likely to generate different support patterns. We therefore expect collective identity to play a prime role in explaining support for European economic governance. Considering that economic transfers to crisis-struck member states might offset nationalistic sentiments, we expect the effect of exclusive national identity to be weaker in poorer countries. 
We analyse a recent Eurobarometer wave (2011) that includes questions referring to proposals to tackle the sovereign debt crisis. Results show that some of the most prominent predictors of EU support fail to explain preferences for economic governance, and that there is surprisingly little correlation between these two orientations. When evaluating European economic governance, citizens tend to consider their country's macro-economic situation. Moreover, people holding an exclusive national identity are less likely to support European economic governance, especially in wealthier member states.

The paper fills a research gap by extending scholarly knowledge on people's willingness to cooperate in the sovereign debt crisis. Considering that national governments are careful not to alienate their electorate by making unpopular decisions on the European level, these findings have important implications for policy makers.

In what follows, we discuss whether previous research on support for free trade and EU support can guide us in formulating our hypotheses, and where we expect different effects with respect to European economic governance. We present the data, operationalizations and methods before showing the results of our empirical analysis. Implications and limitations of our research are discussed.

\section{THEORETICAL FRAMEWORK}

Given the recency of the European sovereign debt crisis, little research exists on support for European economic governance in the crisis (but see Bechtel et al. 2012, 2013 and Daniele and Geys 2012). However, attitudes towards European integration and towards free trade have been widely studied. European integration, free trade and European economic governance all refer to the internationalization of national economies. These strands of research have considerable similarities to our research question. However, as we argue in this paper, there are some fundamental differences between the consequences of current measures to cushion the sovereign 
debt crisis and the consequences of free trade and of European integration. Thus, while research on EU support and support for free trade guide us in developing our hypotheses, we also highlight to what extent it fails to explain support for European economic governance.

\section{Political identities}

A central finding in research on EU support is that people holding an exclusively national identity are less likely to support European integration (Carey 2002; Hooghe and Marks 2005). Exclusive nationalists seem to perceive European integration as a threat to the cultural and social integrity of their national community (McLaren 2002, 2006). Similarly, euroscepticism is highly correlated with xenophobic attitudes (De Master and Le Roy 2000), outgroup-categorization (De Vreese and Boomgaarden 2005), and anti-immigrant feelings (Lubbers and Scheepers 2007). Similar conclusions have been drawn with respect to attitudes towards trade. For the US, Mansfield and Mutz (2009) find that negative attitudes towards outgroups are significantly associated with hostility towards free trade. Hainmueller and Hiscox (2006) show that the positive effect of educational attainment on support for free trade does not solely reflect people's higher competitiveness (see below), but also their longer exposure to cosmopolitan ideas in education.

The same might be true for European economic governance. Focusing on the Euro, Risse (2003: 487) argues that 'we miss the significance of the advent of the Euro for European political, economic, and social order if we ignore its identity dimension'. A common currency plays an important role in identity politics and has been used as a crucial tool in nation building processes (McNamara 1998). Economic and monetary policy competence is seen as a prime factor of national sovereignty and identity (Hobolt and Leblond 2009; Jones 2002). Exclusive nationalists may react sensitively to the curtailment of such competences, and oppose European economic governance (Müller-Peters 1998). Bechtel and colleagues (2013) find that people expressing cosmopolitan attitudes are significantly less likely to oppose financial bailouts for over-indebted economies. 
Exclusive nationalism could be a crucial predictor of support for European economic governance also because European economics and crisis management is a highly complex topic, and a large portion of European citizens might find it difficult to estimate its consequences. Rather than forming their opinion, Europeans often rely on proxies - cognitive shortcuts that help them in forming an opinion. Díez Medrano and Braun (2012) show that there are no differences in attitudes towards free trade across different socio-demographic groups, and they explain this by arguing that citizens are generally uninformed about its consequences. While free trade support is not the same as support for European economic governance, they both relate to complex and abstract problems of economic internationalization. It is plausible that also with respect to European economic governance, people do not have sufficient information and rely on proxies to form their opinion. One such proxy might be the extent to which people identify as European.

H1: People exclusively identifying as citizens of their national community are less inclined to support European economic governance.

\section{Individual cost-benefit analyses}

An intuitive approach to explain support for European economic governance is to link it to its relative costs and benefits for individuals. While collective identities explain a major chunk of the variance in EU support, citizens also seem to base their opinion on utilitarian cost-benefit analyses (Gabel 1998). The integration process creates new opportunities, but also increases competition (Bartolini 2005). Whether an individual is at the winning or losing side of European integration depends on their socio-economic status. Europeans with higher educational attainment and better occupational skills are generally better able to compete in an integrated labour market, and have been shown to be more pro-European (Gabel 1998; Gabel and Palmer 1995). Moreover, capital liberalization provides new investment opportunities to wealthy individuals. Low-income earners cannot benefit from these opportunities. They are also more 
dependent on welfare state services. People with high incomes and high-status occupations have been shown to be more pro-European (Anderson and Reichert 1995; Gabel and Palmer 1995), also when controlling for competing theories such as political values and cognitive mobilization (Gabel 1998) or perceived cultural and economic group threat (McLaren 2006).

Research on support for free trade has drawn similar conclusions. According to economic trade theory (Stolper and Samuelson 1941), international trade benefits individuals who own abundant factors at home, and hurts those who dispose of others. In advanced economies, the crucial factor is skill endowment. Analysing the 1995 ISSP Module (O'Rourke and Sinnott 2001) finds that the higher people's skills (measured by occupational groups), the less likely they are to support protectionist policies. Mayda and Rodrik (2005) find that highly educated individuals oppose trade restriction in high-wage countries but not in less developed countries. Blonigen (2011) comes to similar results with respect to educational attainment, but not with respect to other indicators of socio-economic background.

In short, individuals with high levels of education and with a better socio-economic position are generally more supportive of free trade and of European integration. To the extent that European economic governance entails a similar process of internationalization as free trade and European integration, one could conclude that human capital (educational outcome and skills) and social class are also crucial determinants of support for European economic integration.

However, contrary to free trade and European integration, European economic governance does not necessarily imply liberalization. Rather, current policy proposals to cushion the negative effects of the crisis aim at more regulation. For example, Barroso's plans for a European Banking Union foresee strict supervision of banks across the Eurozone (Commission 2012a). Consequently, the winner-loser scheme discussed above does not apply to the consequences of European crisis management. It does not create new jobs for highly educated people; neither does it offer new investment opportunities. Ultimately, European economic governance in the 
crisis might primarily benefit people who depend on the welfare state, i.e. the unemployed, retired and low-skilled. Bechtel and colleagues (2012) find that individuals are highly responsive to changes in the policy composition of an international financial bailout. The effect might therefore just be contrary to the one expected above. Arguably, people with lower socioeconomic status and higher dependence on the welfare state are more supportive of European economic governance in the crisis.

H2: The lower an individual's socio-economic status, the stronger is their support for European economic governance.

\section{National economic context}

When assessing economic governance in the crisis, citizens may consider its impact on their country's economy. Research has shown that this is the case with respect to EU support. A country's status as net beneficiary or net recipient of European transfers (Anderson and Reichert 1995; Carrubba 1997; Eichenberg and Dalton 1993) and intra-European trade (Anderson and Reichert 1995) are important predictors of EU support. Indicators of macro-economic performance such as economic growth, inflation and unemployment influence aggregate EU support (Anderson and Kaltenthaler 1996). Hobolt and Leblond (2009) find that the exchange rate is a crucial determinant of support for monetary integration, and that it helps explain shortterm fluctuations in public opinion. Banducci and colleagues (2009) find that support for the Euro is responsive to national inflation rates and currency strength.

Similar observations have been made with respect to support for free trade. A study on Americans' attitudes towards international trade has shown that people base their opinion on sociotropic rather than egocentric utilitarian considerations. People believing that the US economy benefits from international trade are more likely to support trade openness, irrespective of their own expected material gain from it (Mansfield and Mutz 2009). 
It therefore seems plausible that people base their opinion on European economic governance on its expected implications for the national economy. Bechtel and colleagues (2013) find that Germans are more concerned about the repercussions on Germany's economic situation caused by a bailout rather than about the impact on their personal situation. People in crisis-struck countries might put high hopes in European economic governance as a way out of the crisis. Current steps to tackle the crisis involve redistribution of funds to economically instable member states. For example, the European Financial Stabilization Mechanism (EFSM) foresees loans of up to $€ 48.5$ billion to be disbursed over three years to Portugal and Ireland (Commission 2012b). These countries directly benefit from European economic governance; without financial assistance, they might risk bankruptcy. Contrarily, richer member states carry a heavy economic burden to sustain these packages.

H3: Citizens of countries with poor macro-economic performance are more supportive of European economic governance.

\section{The conditioning effect of the national economy}

In addition to exerting a direct effect, the national economy might also have an indirect effect on support for European economic governance by influencing to what extent questions of group identity are mobilized and politicized. It might also determine whether certain issues are perceived as a challenge to national identity. Garry and Tilley (2009) find that the effect of exclusive national identity on EU support is conditioned by the national economy. Similarly, certain contextual factors might influence the effect of exclusive national identity on support for increased intergovernmental cooperation and supranational governance in the economic sphere.

We assume that European economic governance results in material gains for poor countries that perceive it as last resort. We therefore hypothesized that people in poorer member states are generally more supportive of European economic governance. Now, we go further and argue that these material benefits for the national economy might attenuate the negative impact of 
nationalist sentiments on support for European economic governance. Citizens in these countries might, as Garry and Tilley (2009: 367) phrase it with respect to EU support, 'swallow their national pride' in favour of the economic gains resulting from European economic governance.

H4: Exclusive national identity plays a weaker role for public support of EEG in countries with poor macro-economic conditions.

\section{DATA AND METHOD}

These hypotheses are tested in an empirical analysis of data from the Eurobarometer survey wave 75.3. Fieldwork was conducted in the 27 European member states in May 2011, over a year after the beginning of the European sovereign debt crisis (Eichengreen 2012). Several important events took place shortly before and during this period. In December 2010, the European Council agreed on the necessity to establish the European Stability Mechanism, a permanent bailout fund of about 500 billion Euro among Eurozone member states (European Central Bank 2011). In May 2011, Portugal was the third member state (after Greece and Ireland) to be granted a bailout package. Having obtained a bailout fund already in May 2010, Greece received a second bailout in July 2011. When answering the survey, respondents were likely to be influenced by these events.

\section{Dependent variable}

To operationalize support for European economic governance, we use the following battery of items: 'A range of measures to tackle the current financial and economic crisis is being discussed in the European institutions. For each, could you tell me whether you think it would be effective or not: (1) A more important role for the EU in regulating financial services, (2) A closer supervision by the EU of the activities of large financial groups/ most important international financial groups, (3) A stronger coordination of economic policy among all the EU member states, (4) A closer supervision by the EU when public money is used to rescue banks and 
financial institutions, (5) A stronger coordination of economic and financial policies among the countries of the euro area'. This battery seems highly appropriate to answer our research question as it directly refers to the current crisis. ${ }^{i}$ Moreover, as it proposes a wide range of measures, the overall tendency to answer positively is less dependent on whether respondents deem a measure to be effective or not. Rather, the overall tendency to support these questions is likely to reflect people's preferences for more or less economic governance. Therefore, it is useful to combine all items into a factor, the so-called Economic governance index. A Cronbach's alpha of 0.85 and a Kaiser-Meyer-Olkin measure of 0.85 testify of a highly reliable scale. We combine the five items by using the common factor. ${ }^{\text {ii }}$ To ease the interpretation of the results, we transform the scale so that it runs from 0 to 10 . After this transformation, the variable has a mean of 7.2 and a standard deviation of 2. The Economic governance index serves as the dependent variable in all analyses presented in this paper.

\section{Independent variables}

National vs. European identity is often operationalized with the question, 'In the near future, do you perceive yourself as (nationality) only, (nationality) and European, European and (nationality), European only' (Risse 2010). Unfortunately, this item is not included in the present Eurobarometer survey. We therefore operationalize exclusive national identity with the following question: 'Please tell me to what extent it corresponds or not to your own opinion: You feel you are a citizen of the EU - Yes definitely/ Yes, to some extent/ No, not really/ No, definitely not/ don't know'. While, 11.7 percent reported not to feel as a EU citizen at all, 24.7 answered 'not really'. 40.2 percent indicated to feel as a EU citizen to some extent, 22.4 percent said that they definitely felt to be a EU citizen, and one percent gave no answer. Echoing previous research (Garry and Tilley 2009), we recode the respondents having answered 'not really' or 'not at all' as having an exclusive national identity. One could argue that this variable does not necessarily capture exclusive national identity as people might not feel as a citizen of their country nor of the EU. However, Garry and Tilley (2009: 376) refer to evidence from the ISSP that this applies to a 
very small portion of the public (about two percent). We therefore are confident that our results are not significantly influenced.

To measure socio-economic status, we rely on the occupational categories and information on educational attainment provided by Eurobarometer: Manager, white-collar worker, selfemployed, manual worker (reference category), house person, retired, unemployed, and student. Eurobarometer measures educational attainment on the basis of respondents' age when they left full-time education. We create three categories: 'Low education' (reference category) refers to respondents having left education at age fifteen or lower. 'Medium education' captures respondents that left school between age 16 and 19; respondents having left school at age 20 or higher are categorized as highly educated. Eurobarometer provides no information on people's income.

A country's macro-economic situation is captured both in subjective and in objective terms. The subjective measure refers to respondents' assessment of the current situation of the national economy (Very bad/ rather bad/ rather good/ very good/ don't know). The objective measures refer to a country's economic growth rate and GDP per capita for the year 2010 .ii $^{\text {iii }}$

\section{Control variables}

Women have been shown to be more reserved towards open trade (Burgoon and Hiscox 2004) and towards European integration (Nelson and Guth 2000). We include a binary variable for being female. We control for respondents' age as younger people have been found to have more supranational identities (Jung 2008). People with extreme political ideologies (at the left and at the right) tend to be more eurosceptical (De Vries and Edwards 2009). Equally, Bechtel and colleagues (2013) find supporters of extremist parties to be more sceptical towards financial bailouts. We control for extreme political ideologies using an item on self-placement on the leftright scale running from 1 (extreme left) to 10 (extreme right). We recode this variable into a number of dichotomous variables. People having placed themselves on 1-2 are coded as 'extreme 
left' (7.6 percent), people on 3-4 are in the category 'moderate left' (16.4 percent), while respondents having chosen 5 and 6 are coded as 'centre' (32.4 percent). The variable 'moderate right' (16.7 percent) refers to respondents having placed themselves on 7 and 8 , whereas people having indicated 9 or 10 are coded as 'extreme right' ( 6.4 percent). Given the high percentage of refusals (8.6 percent) and 'don't know' answers (12,1 percent), we include dummy variables for these two answer categories. Additionally, we control for generalized EU trust by including an additive scale. This scale combines three items on people's trust in the European Commission, the European Parliament, and the EU. Considering the high number of 'don't know' answers, these are recoded as middle categories. This scale is highly reliable with a Cronbach's alpha of 0.9. iv At the country level, we control for adhering to the Eurozone, and for a member state's net transfer in relation to its gross national income. All independent and control variables are grand mean centred. Hence, the intercept reflects the centre of the data and the cross-level interaction can be evaluated more easily. Considering that individuals are clustered within countries, multilevel models with random coefficient are estimated.

\section{RESULTS}

Before turning to the multivariate analyses, we inspect the country-level differences in support for European economic governance and compare them to variation in public support for European integration. Support for European integration is measured using the item asking whether respondents deem their country's EU membership to be a good thing. ${ }^{\mathrm{v}}$ Yet, these variables are on different scales. To compare them, we use standardized versions of the two measures (where each variable has a mean of zero and standard deviation of one). Figure 1 plots aggregate levels of EU support and support for European economic governance for each country side by side, sorted by EU membership support. The countries range from the most proEuropean countries on top to the most eurosceptical member states at the bottom. In the United Kingdom, Latvia, Hungary and Austria, support for European economic governance and EU 
support correlate highly and are both low. Irish respondents are both supportive of European integration and European economic governance. These exceptions aside, there is a remarkable difference between EU support and support for European economic governance in most countries. Support for European economic governance is low in Sweden, Poland, Denmark and Lithuania despite relatively high levels of support for European integration in these countries. In Greece, Cyprus, Slovenia, and Malta, support for European economic governance is more pronounced than support for European integration. Interestingly, in three of the crisis-struck countries (Greece, Portugal, Spain), support for European economic governance is by far greater than support for European integration.

\section{< Figure 1 about here >}

Model 1 in Table 1 shows the results of a multilevel model with the individual-level variables only. While a likelihood-ratio test reveals that the full model explains a significant amount of variance, few of the variables have a significant effect. This is striking as most of the variables have been shown to be strong predictors of EU support. ${ }^{\mathrm{vi}}$ An exception to this is exclusive national identity. Model 1 shows that it has a statistically significant effect on support for European economic governance. Holding all variables at their means and reference categories, having an exclusive national identity lowers the score of our dependent variable by about four percent. This confirms hypothesis 1.

In contrast, we find only limited support for hypothesis 2 that socio-economic status is negatively related to support for European economic governance. Education has no statistically significant effect on support for European economic governance. We expected occupational status to affect our dependent variable. However, only the unemployed indicate a significantly higher support for European economic governance than blue-collar workers (our reference category), while occupation does not matter in any other way. It seems that those who are economically most

vulnerable - the unemployed - see European economic governance as a strategy that might 
improve their situation, thereby giving some support for hypothesis 2 . These findings confirm experimental research by Bechtel and colleagues (2013) that suggested that individuals' economic situation had little influence on their attitudes towards international financial bailouts.

\section{$<$ Table 1 about here $>$}

Only few additional variables significantly influence preferences for EU economic governance. Higher trust in EU institutions increases support for EU economic governance. A respondent's self-assessment of her personal economic situation has no significant effect, while support for European economic governance is higher when a respondent thinks her country's economic situation is problematic. Surprisingly, an extreme left-wing or right-wing political orientation compared to a position in the centre has no significant effect. This might be due to the pooling of 27 countries with different party systems, including countries from East and Western Europe. Support for European economic governance is significantly higher among older respondents, but this effect is very small.

Model 2 accounts for economic growth, EU net-fiscal transfer, GDP per capita, and being an EMU-member. Support for European economic governance is about 8 percent higher in the country with the lowest growth rate in Europe (Greece) than in the country with the highest growth rate (Sweden). This supports hypothesis 3 that citizens in countries with poor macroeconomic indicators tend to be more supportive of European economic governance. Support for economic governance among citizens in EMU countries is about 7 percent higher than support for EEG among EU member states outside of the Eurozone. Net fiscal transfer has a negative effect on support for EEG, which runs counter to earlier findings on the role of EU budget returns for public support of European integration (e.g. Anderson and Reichert 1995, Hooghe and Marks 2005). All effects found in model 1 are robust when including the macro-level indicators in model 2. 
To test hypothesis 4 on the conditioning effect of the national economy, an interaction term (identity* GDP per capita) was included in model 2. ${ }^{\text {vii }}$ The interaction indicates that the negative effect of an exclusive national identity on support for European economic governance strongly depends on a country's GDP per capita. Figure 2 shows the marginal effect of national identity across the whole range of GDP per capita. It reveals that the negative interaction effect is significant across almost all values of GDP per capita. On average, exclusive nationalists in countries with a low GDP per capita (e.g. Romania, Bulgaria) support European economic governance by about 2 percentage points less than those with an inclusive national identity. When GDP is at its EU-wide maximum (e.g. Luxembourg, Denmark), exclusive nationalists differ from those with an inclusive identity by about 8 percentage points. These findings suggest that the negative effect of exclusive national identity is weaker in poorer member states, and support hypothesis $4 .^{\text {viii }}$

\section{CONCLUSIONS}

To what extent do Europeans support economic governance to grapple the consequences of the current sovereign debt crisis? This paper has sought to answer this question using a crossnational analysis of Eurobarometer data from the EU-27 in 2011.

The most striking finding is that support for European economic governance is not the same as support for European integration. The Economic government index correlates rather weakly with EU membership support. Moreover, while support for European integration has decreased considerably in the crisis, the mean of 7.2 on the European economic governance index running from 0 to 10 indicates that Europeans are generally supportive of European economic governance. This finding seems contradictory at first, but arguably reflects the general attitude that the perceived culprits of the sovereign debt crisis should be the ones to fix it. 
The discrepancy between EU support and support for European economic governance suggests potential avenues for increasing the democratic legitimacy of the EU: By assuming an active role as effective crisis manager, the EU could achieve output-legitimacy, i.e. the 'effectiveness in achieving the goals, and avoiding the dangers, that citizens collectively care about' (Scharpf 1997:19). In contrast, in the current handling of the crisis, the European Commission seems to leave the floor to national governments, most notably Germany and France.

Some of the 'usual suspects' that explain orientations towards European integration fail to predict support for European economic governance. Educational attainment, a powerful predictor of EU support and of free trade preferences, has no impact on the Economic governance index. The same is true for occupational groups. Only being unemployed significantly increases support for economic governance. We only find limited support for the hypothesis on a relationship between socio-economic background and attitudes towards European economic governance.

A possible explanation for this is that interests and views on socio-cultural changes can offset each other. Research has shown that highly educated individuals are more supportive of free trade not only because it is in their material interest but also because they have been socialized to endorse trade openness (Hainmueller and Hiscox 2006). Margalit (2012) found that highly educated individuals support free trade even if it is against their interest. Highly educated individuals thus seem to have relatively robust positive orientations towards internationalization. Arguably, low educated individuals have relatively stable reservations against internationalization, which might prevent them to endorse European economic governance even if it is in their interest.

Results were clearer with respect to sociotropic utilitarian considerations. Growth rate has a strong, significant and negative impact on support for European economic governance. The better a country's economy, the less are its citizens inclined to endorse economic governance. This finding suggests that people in economically healthy member states are afraid that European 
economic governance may harm their economy, while people in crisis-ridden countries welcome it. This is interesting insofar as media reports about Greek and Irish protest against bailouts and the ensuing austerity programmes suggest the contrary. In the light of the finding of this paper, these protests do not seem to reflect the overall tendency in their countries.

The results of this paper suggest that exclusive nationalists are less likely to endorse European economic governance. This finding can be interpreted in two ways. On the one hand, it supports previous claims that economic governance touches upon a topic that people with strong national identities are quite sensitive about - macro-economic sovereignty. This policy field is one of the last remains of the Westphalian nation state, and efforts to transfer it to the European level can provoke resentment among exclusive nationalists. To endorse European economic governance, one has to at least weakly identify with Europe. This suggests that the elusive concept of 'European identity' does have behavioural consequences in daily life.

We showed that in poor member states exclusive national identity has a weaker impact on European economic governance. This indicates that the expected economic gains from European economic governance partly offset the identity-based reservations of people with exclusive national identities. One could argue that citizens in poor member states perceive the constraints on national sovereignty imposed by European economic governance as a bitter, but necessary, pill to swallow. They arguably perceive economic constraints as ultimately bolstering the situation of their national economy. Therefore, national identity is less of a constraint to European economic governance in crisis-struck countries than elsewhere. In contrast, in economically stable states, European economic governance is likely to be perceived as an additional burden of responsibilities and costs, thereby aggravating the negative effect of national identity.

The conditioning effect of the national economy suggests that exclusive national identity may, but does not necessarily have to be mobilized against European integration. In some European countries, people exclusively identify with their nation state without being overly eurosceptical. 
What matters is the national context, and more precisely, whether European integration is perceived as a threat to the national community.

Biographical notes: Theresa Kuhn is Lecturer in Sociology at Freie Universität Berlin. Florian Stoeckel is a Ph.D. candidate in Political Science at the University of North Carolina at Chapel Hill, USA.

Address for correspondence: Theresa Kuhn, Freie Universität Berlin, Institute of Sociology, Garystr. 55, 14195 Berlin, Germany. email: theresa.kuhn@,fu-berlin.de, www.theresakuhn.eu / Florian Stoeckel, University of North Carolina at Chapel Hill, Department of Political Science, Hamilton Hall, CB \#3265 Chapel Hill, NC, USA 27599-3265. email: fs@unc.edu

\section{ACKNOWLEDGEMENTS}

Both authors contributed equally to the article. The article was written while the authors were visiting fellows at KFG “The Transformative Power of Europe”, Freie Universität Berlin. We thank Liesbet Hooghe, Hanna Kleider, Heike Klüver, Christian Rauh and the anonymous reviewers for valuable comments and suggestions. Usual disclaimers apply. 
i All but question (5) relate to the EU rather than to the Eurozone. Results remain robust when excluding the question (5).

ii A factor analysis yields one common factor with an eigenvalue of 2.65. The factor loadings for the five variables are between .70 and .75 .

iii We use the natural log of GDP per capita. Results hold when the raw score of GDP per capita is used.

iv Given the cueing capacity of mass media and political parties on EU issues, it would be desirable to account for media use and political affiliations. No such information is provided in the survey.

$\checkmark$ Answer categories are good thing/neither nor/bad thing (Eurobarometer 75.1).

vi A multilevel ordered logit model predicting EU membership support confirms existing research: Most independent variables are significant at the $\mathrm{p}<0.05$ level. Education, occupation, optimistic evaluations of the personal economic situation and of the national economy, trust in EU institutions, and being female is associated with higher EU support. Exclusive national identity, being extreme-left, and being older is associated with less EU support. Including EU membership support as an additional predictor of support for European economic governance does not affect the substantive results.

vii To examine the relationship between alternative macro-economic indicators and identity, we also interacted exclusive national identity with GDP growth and unemployment rate. To see whether utilitarian considerations depend on macro-economic conditions, we interacted occupation, education, and personal financial situation with our macro-economic variables. None of the results suggest a significant interaction.

viii Robustness checks examine the effect of potential outliers: The results hold when excluding respondents in the lowest 5 th percentile of the (skewed) dependent variable of each country. Cook's D for the multilevel case (Möhring and Schmidt 2012) checks for country-level outliers. While seven countries have a high leverage on the model parameters, results hold when excluding these cases successively. 


\section{REFERENCES}

Anderson, C. and Kaltenthaler, K. (1996) 'The dynamics of public opinion toward European integration', European Journal of International Relations 2(2): 175-99.

Anderson, C.J. and Reichert, S. (1995) 'Economic benefits and support for membership in the EU: a cross-national analysis', Journal of Public Policy 15(3): 231-49.

Banducci, S.A., Karp, J. and Loedel, P. (2009) 'Economic interests and public support for the Euro', Journal of European Public Policy 16(4): 564-81.

Bartolini, S. (2005) Restructuring Europe: Centre Formation, System Building, and Political Structuring between Nation State and the European Union, Cambridge: Cambridge University Press.

Bechtel, M., Hainmueller, J. and Margalit, Y. (2012) 'Studying public opinion on multidimensional policies: the case of the Eurozone bailouts', MIT Political Science Department Research Paper 201227.

Bechtel, M., Hainmueller, J. and Margalit, Y. (2013) 'Preferences for International Redistribution. The Divide over the Eurozone Bailouts'. American Journal of Political Science forthcoming.

Blonigen, B. (2011) 'Revisiting the evidence on trade policy preferences', Journal of International Economics 85(1): 129-35.

Burgoon, B. and Hiscox, M. (2004) 'The mysterious case of female protectionism: Gender bias in attitudes toward international trade', UCSD Political Economy Working Papers series. San Diego: University of California at San Diego.

Carey, S. (2002) 'Undivided loyalties: Is national identity an obstacle to European integration?', European Union Politics 3(4): 387-413. 
Carrubba, C. (1997) 'Net financial transfers in the European Union: Who gets what and why?', Journal of Politics 59(2): 469-96.

Crespy, A. (2010) 'When 'Bolkestein' is trapped by the French anti-liberal discourse: A discursiveinstitutionalist account of preference formation in the realm of European Union multi-level politics', Journal of European Public Policy 17(8): 1253-70.

Daniele, G. and Geys, B. (2012) 'Public support for institutionalised solidarity: Europeans' reaction to the establishment of Eurobonds', WZB Discussion Paper SP II 2012-12. Berlin: Wissenschaftszentrum Berlin.

De Master, S. and Le Roy, M. (2000) 'Xenophobia and the European Union', Comparative Politics 32(4): 419-36.

De Vreese, C. and Boomgaarden, H. (2005) 'Projecting EU referendums: Fear of immigration and support for European integration', European Union Politics 6(1): 59-82.

De Vries, C. and Edwards, E. (2009) 'Taking Europe to its extremes: extremist parties and public Euroscepticism', Party Politics 15(1): 5-28.

Díez Medrano, J. and Braun, M. (2012) 'Uninformed citizens and support for free trade', Review of Intenational Political Economy 19(3): 448-76.

Eichenberg, R.C. and Dalton, R.J. (1993) 'Europeans and the European Union: the dynamics of public support for European integration', International Organization 47(4): 507-34.

Eichengreen, B. (2012) 'European monetary integration with benefit of hindsight', Journal of Common Market Studies 50(s1): 123-36.

European Central Bank (2011) 'The European Stability Mechanism', ECB Monthly Bulletin, July 2011, 71-84. 
European Commission (2012a) 'Communication from the Commission to the European Parliament and the Council. A roadmap towards a banking union', COM(2012) 510 final.

European Commission (2012b) 'European Financial Stablisation Mechanism', available at http://ec.europa.eu/economy_finance/eu_borrower/efsm/index_en.htm. (accessed 30.11. 2012).

Gabel, M. (1998) 'Public support for Europe: an empirical test of five theories', Journal of Politics 60: 333-54.

Gabel, M. and Palmer, H. (1995) 'Understanding variation in public support for European integration', European Journal of Political Research 27(1): 3-19.

Garry, J. and Tilley, J. (2009) 'The macroeconomic factors conditioning the impact of identity on attitudes towards the EU', European Union Politics 10(3): 361-79.

Hainmueller, J. and Hiscox, M. (2006) 'Learning to love globalization: the effects of education on individual attitudes toward international trade', International Organization 60(2): 469-98.

Hobolt, S. and Leblond, P. (2009) 'Is my crown better than your Euro?: Exchange rates and public opinion on the European single currency', European Union Politics 10(2): 202-25.

Hooghe, L. and Marks, G. (2005) 'Calculation, community and cues', European Union Politics 6(4): 419-43.

Jones, E. (2002) The Politics of Economic and Monetary Union: Integration and Idiosyncrasy, Lanham: Rowman \& Littlefield.

Jung, J.K. (2008) 'Growing supranational identities in a globalising world? A multilevel analysis of the World Values Surveys', European Journal of Political Research 47(5): 578 - 609. 
Lubbers, M. and Scheepers, P. (2007) 'Explanations of political Euro-scepticism at the individual, regional and national levels', European Societies 9(4): 643-69.

Mansfield, E.D. and Mutz, D.C. (2009) 'Support for free trade: Self-interest, sociotropic politics, and out-group anxiety', International Organization 63(3): 425-57.

Margalit, Y. (2012) 'Lost in globalization: international economic integration and thesources of popular discontent', International Studies Quarterly 56(3): 484-500.

Mayda, A. and Rodrik, D. (2005) 'Why are some people (and countries) more protectionist than others?', European Economic Review 49(6): 1393-430.

McLaren, L. (2002) 'Public support for the European Union: cost/benefit analysis or perceived cultural threat?', Journal of Politics 64(2): 551-88.

McLaren, L. (2006) Identity, Interests and Attitudes to European Integration, Houndsmills: Palgrave Macmillan.

McNamara, K. (1998) The Currency of Ideas: Monetary Politics in the European Union, Ithaca, NY: Cornell University Press.

Möhring, K. and Schmidt, A. (2012) 'Multilevel tools', German Stata Users' Group Meetings, Berlin.

Müller-Peters, A. (1998) 'The significance of national pride and national identity to the attitude toward the single European currency: a Europe-wide comparison', Journal of Economic Psychology 19(6): 701-19.

Nelson, B. and Guth, J. (2000) 'Exploring the gender gap: Women, men and public attitudes toward European Integration', European Union Politics 1(3): 267-91. 
O'Rourke, K. and Sinnott, R. (2001) 'The determinants of individual trade policy preferences: international survey evidence', In S. M. Collins and D. Rodrik (eds), Brookings Trade Forum 2001, Washington, DC: Brookings Institute Press, pp. 157-196.

Risse, T. (2003) 'The Euro between national and European identity', Journal of European Public Policy 10(4): 487-505.

Risse, T. (2010) A Community of Europeans? Transnational Identities and Public Spheres, Ithaca, NY: Cornell University Press.

Scharpf, F. (1997) 'Economic integration, democracy, and the welfare state', Journal of European Public Policy 4: 18-36.

Stolper, W. and Samuelson, P. (1941) 'Protection of real wages', Review of Economic Studies 9: 58-73. 
Table 1: Results of multilevel regression models

\begin{tabular}{|c|c|c|c|c|}
\hline \multirow{2}{*}{ 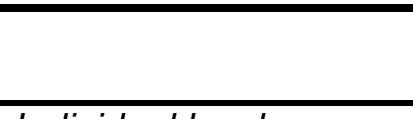 } & \multicolumn{2}{|c|}{ Model 1} & \multicolumn{2}{|c|}{ Model 2} \\
\hline & Coef. & SE & Coef. & SE \\
\hline \multicolumn{5}{|l|}{$\begin{array}{l}\text { Individual level } \\
\text { variables: }\end{array}$} \\
\hline Exclusive national ID & $-0.386^{* * *}$ & 0.030 & $-0.364^{* * *}$ & 0.070 \\
\hline Excl. nat. ID*GDP p.c. & & & $-0.337^{+}$ & 0.270 \\
\hline Education-medium & 0.043 & 0.038 & 0.038 & 0.038 \\
\hline Education-high & -0.023 & 0.044 & -0.032 & 0.043 \\
\hline \multicolumn{5}{|l|}{ Occupation: } \\
\hline Self-employed & 0.056 & 0.055 & 0.066 & 0.055 \\
\hline Managers & -0.017 & 0.051 & -0.004 & 0.051 \\
\hline Other white collar & 0.016 & 0.048 & 0.029 & 0.048 \\
\hline House people & 0.011 & 0.062 & 0.017 & 0.062 \\
\hline Unemployed & $0.124^{*}$ & 0.053 & $0.122^{*}$ & 0.052 \\
\hline Retired & 0.027 & 0.048 & 0.036 & 0.048 \\
\hline Students & 0.007 & 0.070 & 0.008 & 0.069 \\
\hline Trust in EU institutions & $0.367^{* * *}$ & 0.016 & $0.362^{* * *}$ & 0.016 \\
\hline Person. finan. situation & 0.037 & 0.020 & 0.036 & 0.020 \\
\hline Nation. finan. situation & $-0.111^{* * *}$ & 0.021 & $-0.112^{* * *}$ & 0.021 \\
\hline \multicolumn{5}{|l|}{ Political Orientation: } \\
\hline Extreme left & -0.076 & 0.051 & -0.076 & 0.051 \\
\hline Moderate left & -0.040 & 0.038 & -0.049 & 0.038 \\
\hline Moderate right & $-0.136^{\star * *}$ & 0.038 & $-0.130^{* * *}$ & 0.038 \\
\hline Extreme right & -0.036 & 0.054 & -0.019 & 0.054 \\
\hline refused & 0.004 & 0.051 & 0.008 & 0.051 \\
\hline Don't know & 0.051 & 0.050 & 0.047 & 0.050 \\
\hline $\operatorname{sex}$ & -0.006 & 0.026 & -0.006 & 0.026 \\
\hline age & $0.004^{* *}$ & 0.001 & $0.003^{* *}$ & 0.001 \\
\hline \multicolumn{5}{|l|}{ Country level variables: } \\
\hline Growth & & & $-0.086^{* * *}$ & 0.037 \\
\hline EMU-dummy & & & $0.683^{* * *}$ & 0.156 \\
\hline Net fiscal transfer & & & $-0.208^{\star * *}$ & 0.060 \\
\hline GDP per capita (log) & & & $-0.774^{\star \star}$ & 0.270 \\
\hline Intercept & $7.160^{\star * *}$ & 0.130 & $6.728^{* \star *}$ & 0.138 \\
\hline \multicolumn{5}{|l|}{ Variance components: } \\
\hline Individual level & $3.511^{* * *}$ & 0.033 & $3.487^{* * *}$ & 0.033 \\
\hline Country level & $0.311^{* * *}$ & 0.083 & $0.106^{* * *}$ & 0.043 \\
\hline$N L 1 / L 2$ & $21892 / 27$ & & $21892 / 27$ & \\
\hline$-2 *$ Ioglikelihood & 89737.244 & & 89606.468 & \\
\hline \multicolumn{5}{|c|}{$\begin{array}{l}{ }^{+} p<0.10,{ }^{*} p<0.05,{ }^{* *} p<0.01,{ }^{* * *} p<0.001 \text {, two-tailed test; reference categories: occupation } \\
\text { (worker), political orientation (center), gender (female); non-EMU; all independent variables } \\
\text { grand mean centred. Multilevel random intercept random slope model with maximum likelihood } \\
\text { estimates. }\end{array}$} \\
\hline
\end{tabular}


Figure 1: EU Support and Support for European economic governance

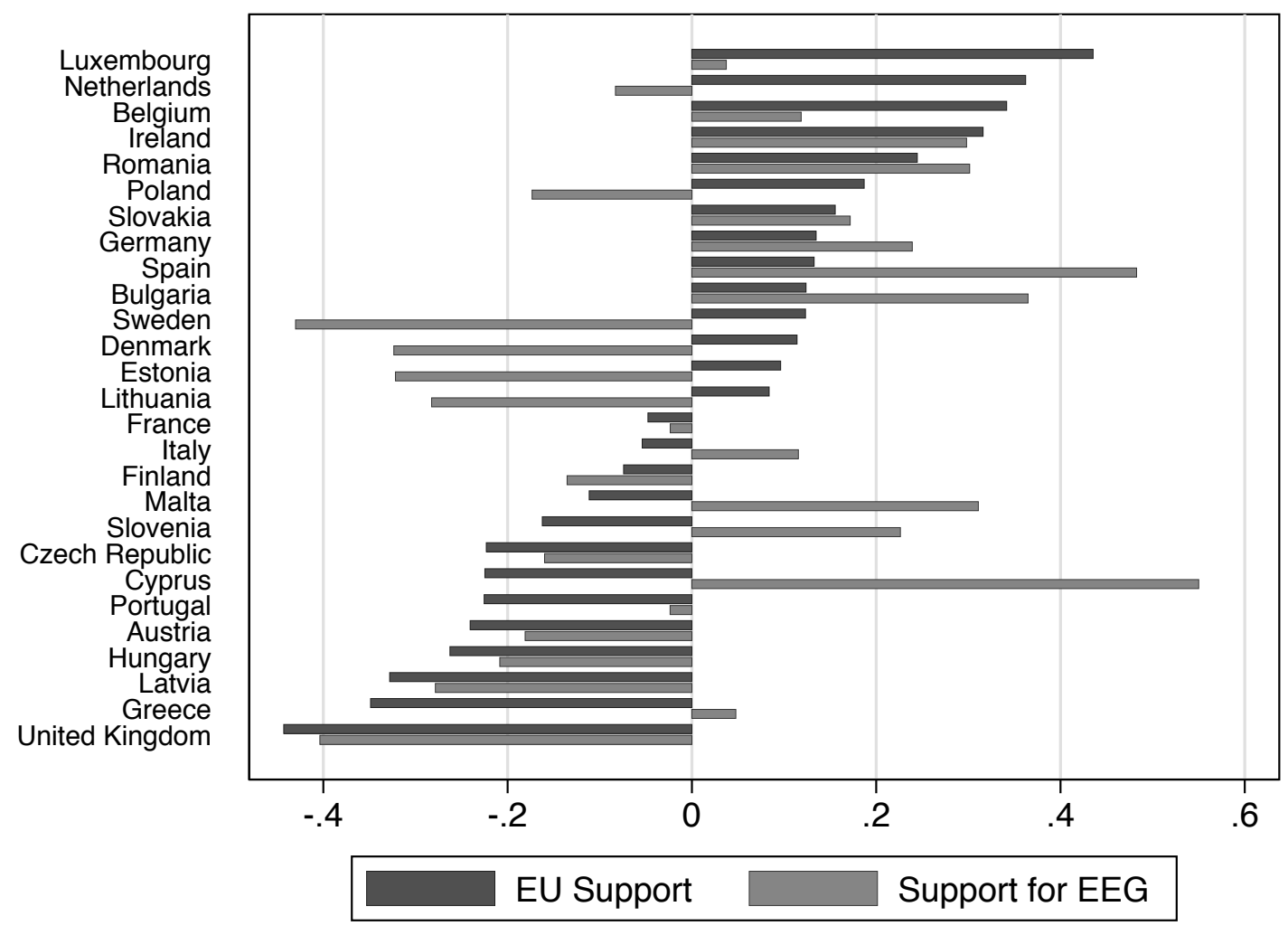


Figure 2: Marginal effect of exclusive national identity on support for European economic governance

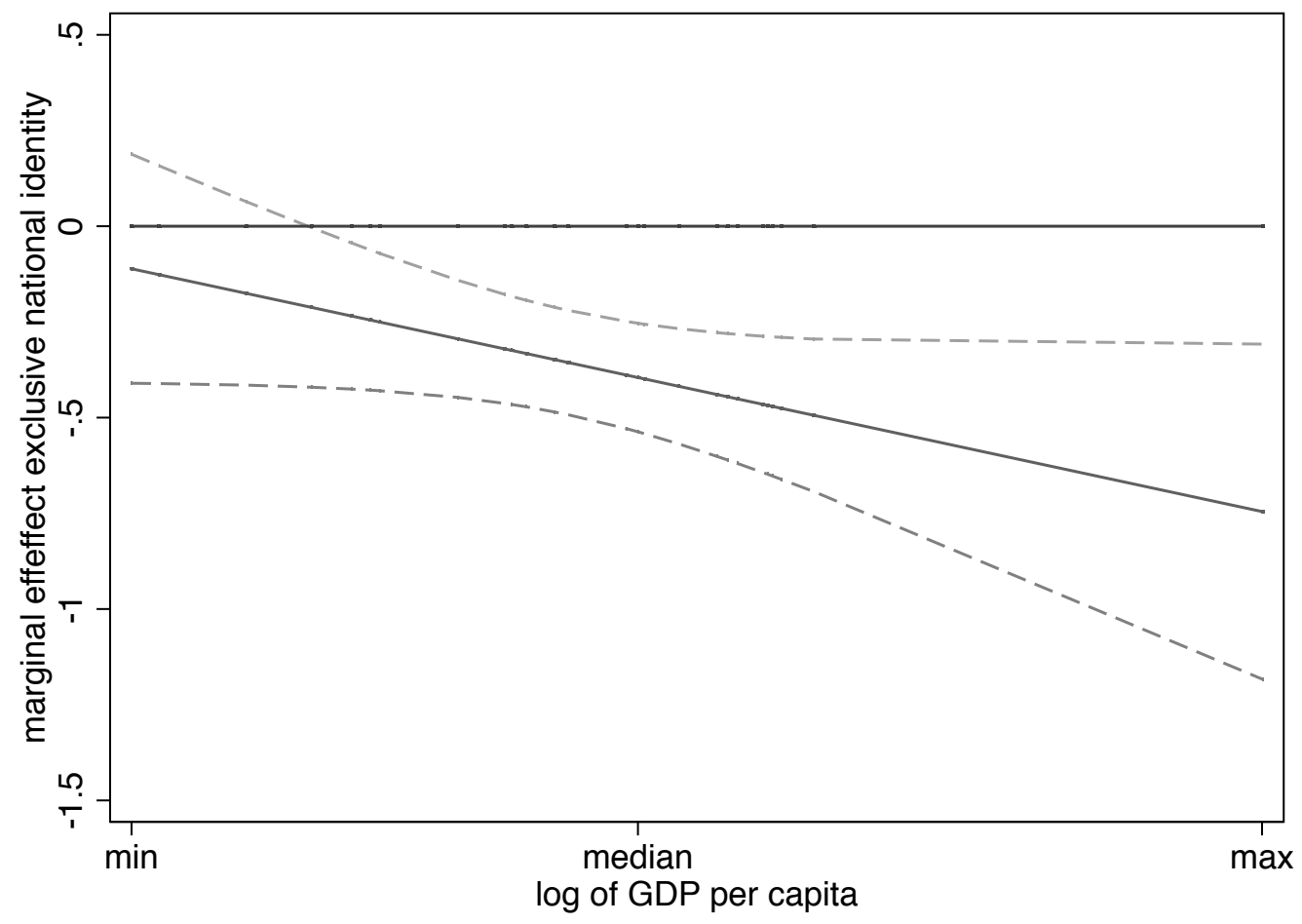

